\title{
THE EFFECT OF LEARNING METHODS AND THE ABILITY OF STUDENTS THINK LOGICALLY TO THE LEARNING OUTCOMES ON NATURAL SCIENCES OF GRADE IV’S STUDENT
}

\author{
Ary Kiswanto ${ }^{\mathrm{a}}$

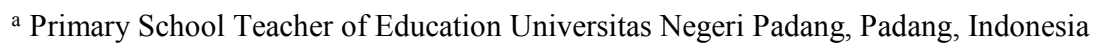

Corresponding e-mail: arykenedi@,gmail.com

\begin{abstract}
This study aims to determine the effect of the Problem Based Learning method and exsperiment method and the ability to think logically of student to the learning outcomes on natural sciences of student of elementary school. The study was conducted at the grade IV SDN 10 Sapiran. Research design using experiment method with treatment by level $2 \times 2$. Data analysis is the two way anava. The results of this study indicate that (1) There are differences in learning outcomes of natural science between the students learn by Problem Based Learning method and the students learn by exsperiment method. (2) There are interactions between learning method and the ability to think logically of student to the learning outcomes on natural sciences of student of elementary school. (3) Learning outcomes of natural science of elementary school between the learned with the learning the problem based learning with the ability logically high higher than students learn with the learning experiment with the ability logically high .(4) Learning outcomes of natural science of elementary school between the learned with the learning the problem based learning with the ability logically low lower than the students learn with the learning experiment with the ability logically low.
\end{abstract}

Keywords: PBL method, exsperiment method, think logically, elementary school 


\section{INTRODUCTION}

Science is a way to find out about the universe through the data set obtained via tail observation and controlled studies. Science is both a body of knowledge that represents the current understanding of natural systems and the process whereby that body of knowledge has been established and is being continually extended, refined, and revised, [1].

Interesting science lessons are not just knowledge of facts, concepts, and theories that are taught simply to the students, but more than that the learning must be meaningful, challenging, and stimulating students' curiosity. In accordance with the purpose of science learning in elementary schools in [2], namely:

(1) Gaining confidence in the greatness of God Almighty based on the existence, beauty, and regularity of His creation. (2) Develop knowledge and understanding of IPA concepts that are useful and applicable in everyday life. (3) Developing curiosity, positive attitude, and awareness about the existence of interrelated relationship between science, environment, technology, and society. (4) Develop process skills to investigate the environment, solve problems, and make decisions. (5) raising awareness to participate in maintaining, preserving and conserving the natural environment, (6) raising awareness to respect nature, its regularity as one of God's creation, and (7) obtaining knowledge supplies, science concepts and skills as a basis for continuing education To SMP / MTs.

Thus, science learning in elementary school is intended so that students can understand the concepts of science, apply it in everyday life, appreciate nature and participate in preserving the natural environment. Students are also required to think critically, creatively, and logically to be able to solve the problems that occur in the environment so as not to adversely affect the survival of humans and other creatures of God.

To form a meaningful learning of science, the teacher must know the characteristics of meaningful learning conditions. [3] states "there are 5 (five) conditions for learnings science meaningfully; (1) existing knowledge is actived; (2) existing knowledge is related to educational experiences; (3) intrinsic motivation is developed; (4) new knowledge is constructed; And (5) new knowledge is applied, evaluated, and revised ".

A survey conducted by TIMSS (Trends in International Mathematics and Science Study) on science learning outcomes in Indonesia said that Indonesia has always been below the average value.
In 1999, Indonesia gained 32 positions from 38 countries with a score of 435 and a participant's average score of 488. In 2003, Indonesia gained 37 positions from 46 countries with a score of 420 and a median score of 474 participating countries. In 2007, Indonesia gained 35 positions from 49 countries with a score of 427 and the average score of participating countries of 500. While in 2011, Indonesia gained position 40 of 42 countries with a score of 406 and the average score of participating countries of 500. Based on the survey above can be deduced that the quality of science teaching Indonesia in the international arena still need to be improved. Improving the quality of science learning can be done by improving the learning process itself such as using learning methods that can improve learning outcomes.

Based on the results of observations made at SDN 10 Sapiran Bukittinggi city during the learning process of science, teachers have a tendency to use learning methods that do not activate students during teaching so that students tend to be passive because less involved and only accept what is delivered by the teacher. Furthermore, it is explained that learning in the class is emphasized on the mastery of concepts and targets of curriculum achievement so that learning in the classroom does not improve students' creativity. Though the essence of science learning classroom lies in the process so it can not be taught by simply asking students memorize the concept but by understanding the concept based on the existing context in everyday life with adjustments to the material contained in the curriculum. From the observation results also found that students are less motivated in science lesson because of the low interest of students in group learning. Based on the results of the analysis of the final score of semester subjects science, second semester of 2015/2016 grade 4 students SDN 10 Sapiran Bukittinggi from the number of students of 30 people, there are 12 people $(40 \%)$ who reach the Minimum Exhaustiveness Criteria (MEC) - average grade of 68.4.

Based on the above explanation, it takes a transformation of learning methods based on student activity. A method of learning that does not require students to memorize facts, but a method that encourages students to construct knowledge in their minds. In addition, the need for a method capable of activating students and fostering student creativity.

Teaching methods that can be considered suitable for achieving these objectives is learning by using methods that are not in one direction and the interaction that involves students in learning one of them is a method of learning Problem Based 
Learning (PBL) And experimental learning methods. This can be seen from the results of research conducted by [4] states that:

"The PBL approach encourages students to actively approach a variety of learning outcomes. Rather than a learning facts passively, students have to engage in self-directed learning and the feedback provided, and apply the information learned. The PBL-based practical class ensures that the learning process and feedback provision are aligned to maximize student experience. The detailed grading scheme made the feedback provision easy and effective, which may be used for class sizes."

According Boud, Felleti and Fogarty cited [5], states that PBL is a learning approach to create confrontation to learners (students-students) with practical problems, the form of ill-sructured, or open-ended through stimulus in learning .

$\mathrm{PBL}$ as one strategy has advantages and weaknesses that must be considered by a teacher so that learning can be done effectively and efficiently. According to [6] PBL has several advantages, namely: (1) realistic with the life of learners, (2) concepts according to the needs of learners, (3) nurture the nature of the inquiry of learners, (4) the retention concept is strong, And (5) cultivate problem solving skills ".

The steps of PBL [7] are: (1) Finding the problem; (2) Building a working structure; (3) Define the problem; (4) Collecting and sharing information; (5) Formulate solutions; (6) Determine the best solution; (7) Present a solution.

In addition, [8] stated that the use of experimental methods in science teaching has a good influence on the achievement of science learning.

The experimental method is a way of presenting the lesson, where students experiment with experiencing and proving themselves something learned, [9]. The purpose of the experimental method proposed are as follows: (1) the student is able to gather the facts, information or data obtained; (2) train students in designing, preparing, executing and reporting experiments; (3) train students in using inductive thinking logic to draw conclusions from facts, information or data collected through experiment, [10].

Meanwhile, the procedures or steps in the experimental method are: (1) the preparation stage, in this step consists of: setting experimental goals, providing guidance and establishing the main steps of the experiment, and preparing materials and tools necessary for Experimenting; (2) stages of implementation, this stage consists of including all students in all observations and experiments, conducting question and answer activities and discussions on tested problems, giving students the opportunity to conduct their own experiments, assessing the experimental activities undertaken by the child. 3) Phase follow up experiment. 4) creation of experiment report. 5) assessment of experimental reports, [11].

Therefore, with this method, the role of teachers in learning is more likely to create a more conducive learning conditions such as providing opportunities for students to play more actively exchange information in groups, thinking and responsible. And the method is also one of the learning method that is fun and demands student activeness in achieving the learning goals.

Teaches logical thinking is very important for a person's education. The importance of teaching and developing the ability to think logically should be viewed as something urgent and can not be underestimated again. The ability to think logically has become the goal or guidance of all subjects, including science. That is, when students study the science, students are expected to develop reasoning in a problem and take the right conclusions.

Efforts to facilitate the logical thinking ability to develop become very important. Many studies have proved that logical thinking can influence learning outcomes. Students who have logical thinking levels will tend to get high learning results and vice versa students who have low logical thinking levels tend to get low learning outcomes. This is in accordance with research conducted by [12] showed that student learning outcomes that have high logical thinking ability is higher than in students who have low logical thinking ability. This is similar to the research conducted by [13] say that "therefore, enhancing logical thinking skills of students is Believed to Significantly Increase mathematics success. The point is that the logical thinking ability of students to improve learning outcomes mathematics. It can be explained that students who have high logical thinking ability will influence student learning outcomes. From the above findings it is understood that the ability to think logically elementary school students need to be improved, because it will have positive impact on students' learning ability.

Therefore, researchers interested in incorporating some facts about the teaching method of Problem Based Learning (PBL) and the experimental method is able to improve student learning outcomes, as well as facts about the logical thinking ability of students affect the results of learning to make a new study that has never been done. In addition, researchers made the curriculum in 2013 as a curriculum to be studied that have not been investigated by previous studies. 
In connection with the above explanation, it can be emphasized efforts to improve the learning process through efforts to select the appropriate and innovative learning methods in science teaching in elementary school is a very important requirement to be done. Thus, the learning method Problem Based Learning (PBL) and the experiment is expected to be a very attractive solution for in practice in the classrooms in order to minimize the various barriers to learning students when learning methods are less favorably inclined only associated to one type of learning modality alone.

\section{METHOD}

This study was conducted in 10 Sapiran Elementary School, Bukittinggi city, and Province of West Sumatra. This study lasted for twelve sessions in the second semester of year academic of $2016 / 2017$. The research was conducted by using the experimental method by comparing two methods of Problem Based Learning (PBL) learning and experimental learning method with the moderator variable of logical thinking ability. The design of this study using treatments by level $2 \times 2$.

Testing the validity of the instrument science learning outcomes using the product moment while the reliability test using Cronbach aplha analysis techniques. Testing instrument validity of logical thinking ability using biserial point correlation test while reliability test using technique KR 20 . There are 2 testing phase that is test requirement of normality analysis and Homogeneity.

Hypothesis test using $t$ test that is difference of two mean. The test is done at significance level $\alpha=$ 0,05 . The alternate hypothesis is rejected if $t<t$ table. This means that there is no significant positive influence between the different methods of learning Problem Based Learning (PBL) and Experiments on the results of primary school students. However, if $\mathrm{t}>\mathrm{t}$ table then the alternative hypothesis is accepted, means indicates there are positive influence between the different learning methods Problem Based Learning (PBL) and Experiment on learning outcomes science Elementary School fourth grade students.

\section{RESULT AND DISCUSSION}

The hypothesis test by two-path of variance analysis (ANOVA) and followed by Tukey test. Summary of calculation results of data analysis of two-path ANOVA can be seen in Table 1 below:
Table 1. Interaction Result Between Learning Methods and Ability of Student Logical Thinking on Student Result of Primary School Student of science

\begin{tabular}{|l|c|c|c|c|c|}
\hline \multicolumn{1}{|c|}{$\begin{array}{c}\text { Source of } \\
\text { Variance }\end{array}$} & $\mathrm{Db}$ & $\mathrm{JK}$ & $\mathrm{RJK}$ & $\mathrm{F}_{\text {Count }}$ & $\mathrm{F}_{\text {table }}$ \\
\hline $\begin{array}{l}\text { Between } \\
\text { Columns }\end{array}$ & 1 & 62,5 & 62,50 & 9,11 & 4,11 \\
\hline Between Rows & 1 & 32,4 & 32,40 & 4,72 & 4,11 \\
\hline Interaction & 1 & 202,5 & 202,50 & 29,51 & 4,11 \\
\hline In & 36 & 247 & 6,86 & & \\
\hline Total Reduced & & 39 & 544,4 & & \\
\hline
\end{tabular}

Based on the results of the two-paths of ANOVA calculation in Table 2 above, the hypothesis can be tested as follows:

a. Differences result of elementary school students learn science among groups of students who studied with learning methods Problem Based Learning (A-1) is higher than on learning outcomes for groups of students who studied with experimental learning methods (A 2).

Based on the results of variant analysis (ANOVA), obtained $\mathrm{F}$ count $=9.11$ at tabe $\mathrm{F}(0,05)$ $=4.11$, then $\mathrm{H}_{0}$ is rejected. What this means is there are differences in the results of primary school students learn science learning with Problem Based Learning method $\left(\mathrm{A}_{1}\right)$ and who studied with experimental learning methods $\left(\mathrm{A}_{2}\right)$. With the average value of $\mathrm{X}_{\mathrm{A} 1}$ and $\mathrm{X}_{\mathrm{A} 2}=31.05=28.55$. It can be concluded that the average value of science learning outcomes of elementary school students between groups of students who take the learning by using learning methods Problem Based Learning $\left(A_{1}\right)$ higher in the study group of students who take the learning by using teaching methods of experiments $\left(\mathrm{A}_{2}\right)$.

b. The influence of the interaction between the learning method and the logical thinking ability of the students on the students' learning outcomes.

Use Based on the analysis of variance (ANOVA), obtained $F_{\text {count }}=29.51$ at $F_{\text {table }}(0,05)=4,11$ so $\mathrm{H}_{0}$ is rejected. This means that there is a very significant interaction between the learning method with the ability to think logically on the results of science learning outcomes. After knowing the interaction between learning method and logical thinking ability of elementary school student hence required further test, in because the number of subject in cell (group) is same, then further test used is Tukey test. 
c. Differences Results of Science Learning Between Students Learning by Problem Based Learning Learning Methods (PBL) that Have Logical Critical Thinking Ability and Students Learning by Experimental Learning Methods that Have High Logical Thinking Ability.

\section{Number}

Testing of differences in the results of primary school students learn science in the group of students who have the ability to think logically are learning to Problem Based Learning method with a group of students who study with experimental method using Tukey test showed that the $\mathrm{Q}$ count $=$ 8.4520 and $\mathrm{Q}$ table $=2.042$, then $\mathrm{H}_{0}$ is rejected, meaning that there is a significant difference of science learning outcomes in teaching methods poblem Based learning with learning mtode experiments on groups of students who have the ability to think logically high or $A_{1} B_{1}>A_{2} B_{1}$ because $X_{\mathrm{A} 1 \mathrm{~B} 1} 34.2$ and $\mathrm{X}_{\mathrm{A} 2 \mathrm{~B} 1}=27.2$. The results of this study indicate that, the results of science learning elementary school students between groups of students who are learning with Problem Based Learning method that has a high logical thinking ability is higher than the learning outcomes of students who learn by experimental learning method that has high logical thinking ability.

d. Differences Result of Science Learning Outcomes Between Students Who Are Learning With Problem Based Learning (PBL) Learning Methods That Have Low Logical Thinking Ability And Students Who Learn by Experimental Learning Methods That Have Low Logical Thinking Ability.

Testing of differences in the results of elementary school students learn science in the group of students who have the ability to think logically low learning with learning methods Problem Based Learning with a group of students who studied with experimental learning method using the Tukey test showed that the $\mathrm{Q}_{\text {count }}=2.4148$ and $\mathrm{Q}_{\text {table }}=2.042$, then the $\mathrm{H}_{0}$ is rejected, meaning that there are significant differences in science learning outcomes on poblem Based learning teaching methods with experimental learning method on a group of students who have the ability to think logically low ( $<$ because $X_{\text {A2B } 2} 29.9>X_{\text {A1B2 }}$ $=27.9$ ). It can be concluded that the average value of science learning outcomes study groups by the method of Problem Based Learning to think logically low is lower than the results of elementary school students learn science who studied with experimental methods that have the ability to think logically low.
The aim of this research is to get the reflection of the effect of learning and the ability to learn from the learning process. The result of hypothesis test based on the two paths of Varian analysis (ANOVA) found that there are differences between the science of performance of the groups of students using the PBL methode and the groups of students use experiment method. The test is continued by Tukey test that suggests that the interaction between learning method and the ability to think logically of student to the learning outcomes on the natural sciences of student of elementary school.

The findings obtained in this hypothesis is that there are differences in learning outcomes of elementary school science between students who are learning by PBL and experimental learning method is very significant, that is learning result of science of student with learning method of PBL is higher than student learn by experiment learning method.

This is because in PBL learning method oriented to framework of contruktivesme. In the implementation of PBL learning methods in elementary schools, the focus of learning is on the chosen problem so that the elementary school students not only learn the concepts related to the problem but also the scientific method to solve a problem. Therefore, in learning PBL in elementary school, elementary school students not only understand the concept relevant to the issues that become the center of attention but also gain experience learning related to the skills of applying scientific methods in problem solving and fostering a critical mindset.

This is in line with Piaget's opinion ([15] on the characteristics of elementary school students whose 7-11 years age range says that "concrete thinking operations (7-11 years). Children develop the ability to think systematically, but only when they can refer to concrete objects and activities ". Based on Piaget's theory of cognitive development, primary school age are in the concrete operational period. At this time students learn to refer to objects and concrete activities. In other words piaget states that at this age of direct experience is very important role as a driver of the cognitive development of students. Therefore, in the science of science in elementary school is required method of learning that makes direct experience and students learn from the real object. In this case, this PBL learning method makes concrete problem or direct experience of student as reference in learning process so that easier for student in comprehending learning.

Based on the statistical analysis of the learning outcomes of elementary school students who are influenced by two independent variables in this study, the learning method and logical thinking ability caused the interaction effect. In teaching 
activities the more appropriate the method used, the more effective and efficient learning activities undertaken between teachers and students will ultimately support and deliver the success of student learning and teaching success conducted by teachers (Shahi, 2009: 123). This means that teachers should be able to choose exactly what methods will be used in the learning process by looking at the learning objectives to be achieved, the circumstances and the level of student development, including logical ability siswa. Therefore in the process of learning in primary schools, teachers should be able to Establishing learning methods that are appropriate to students' logical thinking ability in primary schools.

The result of hypothesis testing showed that learning outcomes between elementary school students who studied with PBL learning methods that have high logical thinking ability is higher than student learning outcomes that follow the learning with experimental learning method that has high logical thinking ability.

[15] argues that logic helps humans think straight, efficiently, precisely and orderly to get the truth and avoid mistakes. In other words, the logic helps students to be able to think properly, efficiently and systematically in order to take a correct decision. Thus the elementary school students who master this logical thinking ability correctly will be able to develop the habit of thinking clearly and critically.

Elementary school students who have high logical thinking ability who are given treatment using PBL learning methods can easily understand learning in the learning process. This is because in the process of learning PBL basic school based on a problem developed into materials in the learning process. For elementary school students who have high logical thinking ability will feel comfortable and happy when a learning based on their problems to find a solution. Problems in learning PBL in elementary school is tailored to the problems close to the students so that elementary school students who have high logical thinking ability will easily understand learning. Problems relating to the real world students will encourage students who have high logical thinking ability to make connections between knowledge that is in his with the concept of learning obtained so that students can actively build knowladge.

The test results further show that the science student learning outcomes between the treatment given to the Problem Based Learning teaching methods that have the ability to think logically lower lows experimental learning methods, who has the ability to think logically low.

Elementary school students who have low logical thinking ability who are given treatment with experimental learning method can achieve success in learning because the step in the learning process by using the experimental method is simpler and easier to understand by elementary school students who have low logical thinking ability. In addition, in the process of learning experimental methods for elementary school students, it is easier for elementary school students in understanding learning materials, because in the experimental method the teacher gives the theme of learning and students are asked to conduct experiments with his colleagues without students asked to find a problem that will Made learning first. This makes the elementary school students who have logical thinking ability, which at first they quickly get bored and not enthusiastic in the learning process becomes more active and can improve the skills they have. In addition, elementary school students who have low logical thinking ability will feel comfortable in the learning process, this makes them feel confident over the truth of the conclusion of their experiments.

\section{CONCLUSION}

Based on the results of the analysis and discussion that have been described in this study can be obtained the findings as follows:

First, the learning outcomes of elementary school students who studied with PBL learning methods were higher than those of primary school students who studied with experimental learning methods.

Secondly, there is an interaction effect between the use of learning method and logical thinking ability on the learning outcomes of elementary school students.

Third, the result of science learning elementary school students between students who learn by PBL learning method that has high logical thinking ability higher than the students who learn by experimental learning method that has high logical thinking ability.

Fourth, the results of elementary school students learn science among students learning with learning methods Problem Based Learning (PBL) Which has a lower logical thinking ability lower than students who learn by experimental learning methods that have low logical thinking ability.

Based on the presentation of the above findings, it can be concluded that the influence of learning methods on the results of science learning elementary school students. Elementary school students are learning with Problem Based Learning method to get the results to learn science is higher than elementary school students who studied with experimental methods. The interaction between the use of learning methods and the ability to think 
logically on the results of science learning elementary school students means the influence of interaction between learning methods with the ability to think logically affect the high level of learning outcomes of primary school students. At the elementary school students who have a high logical thinking ability will affect better the learning outcomes of the student when the student learn science to Problem Based Learning method. Conversely, in elementary school students who have a low logical thinking ability will have a better effect on students' learning outcomes if students are taught by experimental methods..

\section{SUGGESTION}

Based on the conclusions in this study then can tell some suggestions as follows: First, to optimize science learning in primary school, it is necessary to use learning method in science learning. Second, if the science teaching in primary schools take into account the ability to think logically high, then to optimize the learning outcomes should be given learning science teaching methods Problem Based Learning in the process of learning science in elementary school. Third, if in science lessons in elementary school take into account the ability of logical thinking is low, then to optimize the results of science learning should be given learning by experimental learning methods in the process of learning science in primary schools.

\section{ACKNOWLEDGMENT}

Thanks to all those who have helped in this research. Thanks to the department of primary education of UNJ, Postgraduate, SDN 10 Sapiran. Thanks to all those involved in this research.

\section{REFERENCES}

[1] Duschl, Richard A, Taking Science To School Learning and Teaching Science in Grades K-8, Washinton DC: The National Academies Press, 2007.

[2] Depdiknas, Kurikulum Tingkat Satuan Pendidikan Jenjang Pendidikan Dasar, Jakarta: BNSP,2006.

[3] Glynn, Shawn M. \& Reiders duit, Learning Science in The Schools. New York; Lawrence Erlbaum Associates, 1995.

[4] Katja Strohfeldt \& Olga Khutoryanskaya, Instructional Design and Assessment Using Problem-Based Learning in a Chemistry Practical Class for Pharmacy Students and Engaging Them with Feedback, American Journal of Pharmaceutical Education 2015; 79 (9) Article 141, p.5.

[5] Ngalimun, Strategi dan Model Pembelajaran, Yogyakarta: Aswaja Pressindo,2014.
[6] Trianto, Mendesain Model Pembelajaran Inovatif-Progresif: Konsep, Landasan, dan Implementtasinya pada Kurikulum Tingkat Satuan Pendidikan (KTSP), Jakarta: Kencana Prenada Media Group,2011.

[7] Abidin, Yunus, Desain Sistem Pembelajaran dalam Konteks Kurikulum 2013, Bandung: Refika Aditama, 2014.

[8] Yuliana, Chelsi, Pengaruh Metode Eksperimen dalam Pembelajaran IPA Terhadap Prestasi Belajar Siswa, www.portalgaruda.org (access on september, 29, 2016)

[9] Djamarih, Syaiful Bahri and Aswan Zain, Strategi Belajar Mengajar, Jakarta: Rineka Cipta, 2010.

[10] Putra, Sitiatava Rizema. Desain Belajar Mengajar Kreatif Berbasis SAINS, Yogyakarta: Diva Press, 2014.

[11] Syah, Darwyan, Strategi Belajar Mengajar, Jakarta: Diadit Media,2008.

[12] Ramouli,Mika. Pengaruh Pembelajaran Matematika Realistik dan Berpikir Logis Terhadap Hasil Belajar Matematika Siswa SD Bharlind School Medan, Jurnal Tematik, Volume : 003/No.12/DIKSAS/Desember 2013, ISSN : 1979-0633, p.1.

[13] Aksu, Gokhan. Determination the Effects of Vocational High School Students' Logical and Critical Thinking Skills on Mathematics Success, Eurasian Journal of Educational Research, Issue 59, 2015, PP.181-206.

[14] Crain, William. Teori Perkembangan Konsep dan Aplikasi. Yogyakarta: Pustaka Pelajar, 2007

[15] Mundiri. Logika. Jakarta: PT Rahjo Grafindo Persada, 2014.

[16] 